\title{
Brexit negotiations: From negotiation space to agreement zones
}

\author{
Ursula $\mathrm{F} \mathrm{Ott}^{1}$ and \\ Pervez N Ghauri ${ }^{2}$ \\ ${ }^{1}$ Nottingham Business School, Nottingham Trent \\ University, Nottingham NG1 4BU, UK; \\ ${ }^{2}$ Birmingham Business School, University of \\ Birmingham, Edgbaston Park Road, \\ Birmingham B15 2TY, UK \\ Correspondence: \\ PN Ghauri, Birmingham Business School, \\ University of Birmingham, Edgbaston Park \\ Road, Birmingham B15 2TY, UK. \\ Tel: +44-121-414 5868; \\ Fax: +44-121-4147380; \\ e-mail: p.ghauri@bham.ac.uk
}

Received: 29 May 2017

Revised: 28 February 2018

Accepted: 10 September 2018

Online publication date: 2 November 2018

\begin{abstract}
Brexit is decidedly a "big question". We agree with International Business scholars who say that such questions need to be addressed using an interdisciplinary approach. We use bargaining theory models of rational behavior and the negotiation literature to explain various Brexit options and predict their consequences. Considering the lack of relevant experiential knowledge, and the multidimensional high-stakes negotiations underway, it is little wonder that anxiety is growing across all 28 European Union member states. Our analysis supports a coherent approach from rational bargaining model to real-life international negotiation. We position outcome scenarios in different agreement zones and explore their ramifications.
\end{abstract}

Journal of International Business Studies (2019) 50, I37-149.

https://doi.org/| 0.1057/s4|267-018-0189-x

Keywords: bargaining theory; negotiation analysis; agreement zone; Brexit negotiations; outcome scenarios

The online version of this article is available Open Access

\section{INTRODUCTION}

Some are doubtful whether international business (IB) research is up to tackling business - and indeed societal-big questions (Buckley, 2002; Buckley, Doh, \& Benischke, 2017). Brexit is undeniably such a question. International business takes place within a framework of institutions that govern the movement of goods, services, capital, and people, basically, the European Union four freedoms spelled out in the Treaty of Rome. These institutions are often challenged by patriotic and nationalist rhetoric. Agreements between nations, firms, and individuals facilitate trade and ensure smooth interaction. The negotiation of such agreements has long been an important research topic for IB scholars (Kapoor, 1970; Money, 1998; Sawyer \& Guetzkow, 1965; Tung, 1982). Especially now, in an era fraught with nationalist movements, IB researchers are challenged to undertake inter-disciplinary and phenomena-driven negotiation research.

Negotiation, as Walton and McKersie (1965: 3) succinctly put it, is "the deliberate interaction of two or more complex social units which are attempting to define or redefine the terms of their interdependence." Lewicki, Weiss, and Lewin (1992) emphasize that negotiations do not only take place between individuals, but 
between groups and organizations. The literature consistently shows that greater gains can be achieved when a negotiation takes place within a single culture than when across a cultural divide (Imai \& Gelfand, 2010), and that the negotiation process is more difficult when parties have different values and traditions (Volkema, 2012). Diverse cultural backgrounds affect the actors, their behavior in negotiations, and hence outcomes (Ghauri, 2003a).

Article 50 of the European Union Lisbon Treaty states that any member state may withdraw from the Union, and spells out the process for doing so. In a referendum held on June 23, 2016, the British electorate voted by a margin of $3.8 \%$ to accept a proposal to exit the EU. Months of uncertainty followed. In March 2017, the UK triggered Article 50 , thereby beginning the process of exiting. A process dubbed Brexit, with far-reaching economic, social, and environmental consequences was underway. Brexit constitutes a major discrete event, which affects governments, firms, and individuals. It also presents an opportunity for IB scholars to examine the negotiation of an interesting set of international business issues and to have a say in an important geo-political event. International business, as a field that combines economics, sociology, psychology, political science, anthropology, and management studies, is ideally positioned to address the Brexit big question.

We investigate the negotiation space - in essence, the ground covered by the UK government and the European Commission representing the states that will remain in the EU - and the agreement zones for Brexit outcomes. After much heated internal political debate, what the UK government would seek to achieve in Brexit negotiations was published in a white paper (HM Government, 2017). This article focuses on the 12 principles set out in that policy statement, i.e., the strategic scenarios over the duration of the Brexit negotiations and the move from negotiation space (where the UK and $\mathrm{EU}$ meet) to agreement zones.

After more than 40 years of UK membership in the EU, the Brexit negotiations involve considerable complexity and uncertainty, and will have a life-changing impact on millions of citizens on both sides. There are an infinite number of potential outcomes in a negotiation like this one, but there are some salient possibilities. There are countries that do not have full EU membership but which do have a close relationship with the EU along the lines of which Brexit might be negotiated
(Malhotra, 2016; Pötsch \& Van Roosebeke, 2017). These countries constitute models as well for Brexit. The UK might look to the (1) Norway model, (2) Switzerland model, (3) Canada model, (4) Ukraine Plus model, (5) Turkey model (in order from high to low trade and immigration integration). It is also possible that no agreement for a future relationship will be struck, i.e., a No Deal option. Article 50 allows up to 2 years after a declaration of the intention to withdraw for the negotiation of a new relationship, a time constraint that adds to the pressure on negotiators. Our research questions are: What negotiation scenarios need to be considered? How will the strategic profiles of the various players influence the outcome? What agreement zones can be envisaged that would allow us to predict the outcome?

The Brexit negotiation space can be analyzed from rational and behavioral perspectives. Interactive decision-making can follow a game theory path with negotiators assumed to be rational players anticipating strategies and the outcome of their choices, or a behavioral one with uncertainties dominating their decision-making. International negotiations fall under the economics of international business with players exhibiting different forms of rationality (Casson \& Wadeson, 2000), i.e., rational, bounded rational, or meta-rational. Raiffa, Richardson, and Metcalfe (2002) see the negotiation process through four lenses: asymmetrically descriptive (psychological), symmetrically prescriptive (game theoretical), asymmetrically descriptive and prescriptive (negotiation analytical), and externally descriptive and prescriptive (conflict resolution via mediators). In summary, rational and behavioral models of decision-making have a place in the negotiation analysis of international business and political negotiations. We apply bargaining theory to the Brexit case and consider zones of feasible and potential agreements.

\section{THE NEGOTIATION SPACE AND NEGOTIATION STRATEGIES}

\section{Political Background}

We start with the state of affairs at the outset of negotiations, sometimes termed the initial endowment. We highlight the policy positions of the UK and $\mathrm{EU}$, then consider the movement of goods, services, capital, and people as important points in the negotiation space. The UK position summarized in the White Paper lists 12 negotiation goals 
Table 1 The UK White Paper 12 principles Source: Based on HM Government, White Paper (2017)

UK Brexit objectives

1. Provide certainty and clarity

2. Take control over own laws

3. Strengthen the union of England, Northern Ireland, Scotland, and Wales

4. Protect ties with the Republic of Ireland and maintain the common travel area

5. Control immigration

6. Secure rights of UK and EU nationals

7. Protect workers' rights

8. Ensure free trade with European markets

9. Secure new trade agreements with third countries

10. Ensure continued science and innovation excellence

11. Cooperate with Europe on crime and terrorism

12. Achieve an orderly and smooth exit
Definitions

Brexit negotiations will be conducted as transparently as possible. Initially, EU law will continue to apply as national law after Brexit. Any Brexit agreement with the EU will be put before both Houses of Parliament for ratification

Laws applicable in the UK will be made in the UK and interpreted only by UK courts, not by the European Court of Justice

The governments of England, Scotland, Northern Ireland, and Wales will work closely together to implement Brexit

The freedom to travel between Northern Ireland and the Republic of Ireland will be maintained

The UK intends to control the number of immigrants from the EU

The rights of EU citizens living in the UK and of UK citizens living in the EU will be guaranteed

The level of protection provided workers under EU law will be maintained and extended

The UK will seek the greatest possible access to the EU single market for goods and services, and be willing in return to make financial contributions to the EU The UK aims to conclude its own free-trade agreements with third countries

The UK aims to continue to collaborate with the EU in the areas of basic science and research and development

The UK aims to continue to collaborate with the EU in the areas of foreign and defense policy and in combating crime and terrorism

The UK seeks to have a transition period, which will allow government and business time to adapt (see Table 1): (1) provide certainty and clarity, (2) take control over own laws, (3) strengthen the union of England, Northern Ireland, Scotland, and Wales, (4) protect ties with the Republic of Ireland and maintain the common travel area, (5) control immigration, (6) secure rights of $\mathrm{UK}$ and $\mathrm{EU}$ nationals, (7) protect workers' rights, (8) ensure free trade with European markets, (9) secure new trade agreements with third countries, (10) ensure continued science and innovation excellence, (11) cooperate with Europe on crime and terrorism, (12) achieve an orderly and smooth exit. It is important to note that the UK is economically dependent on the $\mathrm{EU}$, indeed some $40 \%$ of its exports go to the $\mathrm{EU}$, while just $10 \%$ of EU exports go to the UK.

As for the EU, the European Commission holds that EU trade policy is created and implemented in a transparent and democratic manner and its goal is to serve European citizens by creating jobs and ensuring economic prosperity (EC Tradoc 151381). To this end, European negotiators rely on information received from the public before any negotiations start. During negotiations, the Commission acts on instructions received from the EU member states, and remains throughout fully accountable to them as well as to European civil society and to the
European Parliament (European Commission, $2017 \mathrm{a}, \mathrm{b})$. These terms mean that trade negotiations are usually quite complicated, as agreements must honor and safeguard trade and migration rules. The EU has three main types of agreements (http://ec.europa.eu/trade/policy/countries-andregions/agreements/): Customs Union, which eliminate customs duties in bilateral trade and establish joint customs tariffs on foreign imports, Association Agreements, Stabilization Agreements, Free-Trade Agreements, and Economic Partnership Agreements, which remove or reduce custom duties on bilateral trade, and Partnership and Cooperation Agreements, which provide a general framework for bilateral economic relations leaving as is existing tariffs. The Norway model, Switzerland model, Canada model, and Ukraine Plus model are illustrative of these types of agreements (see Table 2). They are considered to be models that the UK might follow in its negotiations with the EU (Malhotra, 2016; Pötsch \& Van Roosebeke, 2017). We outline each of them briefly below:

Norway model As a member of both the European Free Trade Association (EFTA) and the European Economic Area (EEA), Norway has access to the single market, for which it makes payments to the 
Table 2 Extent to which various deep and special trade agreement models of the EU meet UK objectives Source: Pötsch and Van Roosebeke (2017, p. 5)

\begin{tabular}{|c|c|c|c|c|}
\hline United Kingdom's objectives & $\begin{array}{l}\text { Norway } \\
\text { model }\end{array}$ & $\begin{array}{l}\text { Switzerland } \\
\text { model }\end{array}$ & $\begin{array}{l}\text { Canada } \\
\text { model }\end{array}$ & $\begin{array}{l}\text { Ukraine plus } \\
\text { model }\end{array}$ \\
\hline No application of EU law (Objective 2) & - & $(\sqrt{ })$ & $\sqrt{ }$ & $\sqrt{ }$ \\
\hline No free movement (Objective 5) & - & - & $\sqrt{ }$ & $\sqrt{ }$ \\
\hline Access to the internal market (Objective 8 ) & $\sqrt{ }$ & $(\sqrt{ })$ & $(\sqrt{ })$ & $(\sqrt{ })$ \\
\hline Own trade agreements with third countries (Objective 9) & $\sqrt{ }$ & $\sqrt{ }$ & $\sqrt{ }$ & $\sqrt{ }$ \\
\hline $\begin{array}{l}\text { Collaboration on security and defense policy } \\
\text { (Objective 11) }\end{array}$ & - & - & - & $(\sqrt{ })$ \\
\hline
\end{tabular}

- Does not align with UK objectives.

$(\sqrt{ })$ Partially aligns with UK objectives, but needs special agreements. $\sqrt{ }$ Fully aligns with UK objectives.

EU. Norway is required to abide by the EU 4-freedoms principle of free movement of goods, services, capital, and people. It also must abide by most EU laws but does not have a formal say in their formulation and has no veto rights on their application.

Switzerland model Switzerland is a member of the EFTA, but not the EEA. It has less access to the single market than Norway, but more latitude in the application of EU laws. It is further connected to the EU by various treaties covering specific sectors. There are about 100 bilateral agreements, none of which cover the financial sector. The UK will therefore need to consider whether to use this model with a very strong financial service sector. The Agreement on the Free Movement of Persons (AFMP) finalized this year reduces the ability of Switzerland to place limits on EU citizen immigration.

Canada model The Comprehensive Economic and Trade Agreement (CETA) eliminates 98\% of tariffs. There is visa-free travel between Canada and most EU member states but there is no right of free movement of people between Canada and the EU.

Ukraine Plus model Ukraine, like Canada, has entered a comprehensive free-trade agreement with the EU to remove or reduce tariffs in bilateral trade. There is visa-free travel between Ukraine and most EU member states, but no right of free movement of people between Ukraine and the EU.

Turkey model Turkey and the EU have agreed to a customs zone in which tariffs are imposed. There is no visa-free travel between Turkey and the EU nor is there free movement of people between Turkey and the EU.

No Deal option If no future relationship can be negotiated, World Trade Organization rules with strict regulations on quotas and tariffs would apply, as is currently the case between the United States and the EU.

The UK government's aim is to negotiate an agreement that meets as many of its current and future objectives as possible. This means negotiating a 21-month transition period beyond March 29, 2019 and keeping open options for collaboration on free trade in goods and services, on investment, and on immigration. One UK negotiation position, which has been dubbed "hard Brexit", envisages no exit payment, a single market, and an end of the free movement of people between the UK and the EU. An opinion poll of German economics professors suggests that the best path for achieving the UK-stated goals would be to negotiate a Ukraine Plus Model with a view to eventually being able to negotiate a Norway model (Gäbler, Krause, Kremheller, Loren \& Potrafke, 2017). In the following section, we apply a bargaining model to the positions taken by UK and EU negotiators in order to highlight the complexities and trade-offs involved.

\section{Immigration and Trade Agreements Between the UK and EU - Indifference Curve Analysis}

We use the concept of indifference curves from the Edgeworth box (Edgeworth, 1925) with free movement of goods (trade integration) and of people (immigration integration) as the two "commodities" being traded. The concept of Pareto optimality complements this by helping to determine an optimal allocation of commodities. Pareto optimality is the allocation whereby it is not possible to make one negotiator better off without making any other negotiator worse off. This idea is further developed in game theory as an interactive multi- 
player decision-making game. We use bargaining theory as an application of game theoretical reasoning for an alternating offer scenario. Negotiation space, a concept borrowed as well from the Edgeworth box, is bound by two opposing objectives: (1) the UK is reluctant to allow unfettered EU immigration, and (2) unimpeded EU immigration and trade are jointly the gateway to a future UK-EU relationship. In the case of the $\mathrm{UK}$ and $\mathrm{EU}$, we consider trade integration (Mulabdic, Osnago \& Ruta, 2017), ranging from free-trade agreement, to customs union, to a common market, and to immigrant integration - a scalar view of the UKEU relationship.

We start with trade integration as $x$, and immigration integration as $y$. The indifference curves of the UK and the EU show a similar perspective in terms of negotiation space. In terms of trade integration, $x$, the EU accounts for $40 \%$ of UK trade $\left(x_{\mathrm{EU}}\right)$ compared to $10 \%$ of trade to the UK from the EU $\left(x_{\mathrm{UK}}\right)$. However, according to European Statistics (European Union, 2017), the export of UK goods to other EU member states grew from 100 billion euros in 2003 to 230 billion euros in 2015, highlighting the need for a trade agreement. When it comes to immigration integration, $y_{\mathrm{EU}}$ shows the 2.9 million EU citizens ( $0.6 \%$ of EU population) living and working in the UK, and $y_{\mathrm{UK}}$ shows the 1.2 million UK citizens ( $1.9 \%$ of UK population) living and working in the EU.

The endowment point $\mathbf{W}$, through which the slope of any line passes, represents the ratio of trade integration and immigration integration. Thus, if that line is relatively steep, more has to be given up for immigration than for trade (immigration is relatively more expensive than trade). If the line is relatively flat, then the opposite is true. In the UKEU case, an initial endowment $\mathbf{W}$ represents the UK and EU levels of trade and immigration integration available before negotiations. At the outset, the endowment position is common to both parties. Thus $\left(X_{\mathrm{EU}}, Y_{\mathrm{EU}}\right)=\mathbf{W}_{\mathrm{EU}}$ and $\left(X_{\mathrm{UK}}, Y_{\mathrm{UK}}\right)=\mathbf{W}_{\mathrm{UK}}-$ where $\mathbf{W}_{\mathrm{EU}}$ and $\mathbf{W}_{\mathrm{UK}}$ represent the UK and the EU initial endowments in $\mathbf{W}$. This would fit with the negotiations between the UK and EU. For the different bargaining positions, the two players will need to have their utility functions determined and positioned as in Figure 1.

Nash bargaining suggests that the UK and EU will end up dividing the gains from renegotiation. The UK would prefer to end at the south-west border of the space (on the EU indifference curve) and the EU at the north-east border (on the UK indifference

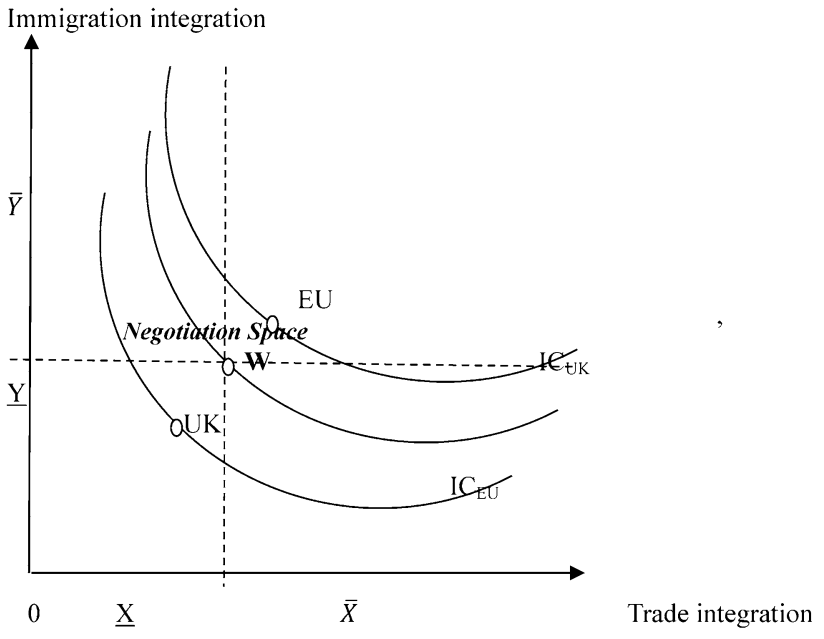

Figure 1 Negotiation space for Brexit models. $X$ Trade integration - from free-trade agreements to customs union to common markets to full trade integration, $Y$ Immigration integration - from restricted immigration to free movement to full integration of immigrants into society, $W$ UK and EU endowment points, IC UK and EU indifference curves (see "Appendix").

curve). Starting from those positions, they eventually end up somewhere in the middle, depending on the degree of symmetry in their bargaining strength. To explain the outcome, we can use a rational approach or a behavioral one.

\section{A GAME THEORETICAL BARGAINING MODEL FOR BREXIT}

The economics literature is rich in bargaining models, (Nash, 1950; Kalai \& Smorodinski, 1975; Rubinstein, 1982; Mas-Collel,Winston \& Green, 1995; Muthoo, 1999). We use the indifference curve analysis presented above to throw light on the Brexit negotiations. We present a stylized representation of an alternatingoffers bargaining game where players attempt to reach an agreement by making offers and counter-offers. This is reflective of most real-life negotiations where bargaining imposes costs on both players.

Let $X$ denote the set of possible agreements for the two players UK and EU, in which $x$ is used for one offer in the agreement set $X$. If the players $i=(\mathrm{EU}, \mathrm{UK})$ reach an agreement at time $t \Delta$ on $x \in X$, then the players' payoff is

$$
U_{i}(x) \exp \left(-r_{i} t \Delta\right)
$$

where $U_{\mathrm{i}}: X \rightarrow R$ is player i's utility function. For each $x \in X, U_{\mathrm{i}}(x)$ is the instantaneous utility that player i obtains from agreement $x$. If the players 
disagree, then each player's payoff is zero. This means a set of possible utility pairs $\Omega=\left\{\left(u_{\mathrm{UK}}, u_{\mathrm{EU}}\right)\right.$, i.e., there exists $x \in X$ such that $U_{\mathrm{UK}}(x)=u_{\mathrm{UK}}$ and $\left.U_{\mathrm{EU}}(x)=u_{\mathrm{EU}}\right\}$ is the set of utility pairs obtainable through agreement. The Pareto frontier $\Omega^{\mathrm{e}}$ of the set $\Omega$ is a key concept in the analysis of the subgame perfect equilibria. A utility pair $\left(u_{\mathrm{EU}}, u_{\mathrm{UK}}\right) \in \Omega^{\mathrm{e}}$ if and only if $\left(u_{\mathrm{UK}}, u_{\mathrm{EU}}\right) \in \Omega$ and there does not exist another utility pair $\left(u_{\mathrm{EU}}^{\prime}, u_{\mathrm{UK}}^{\prime}\right) \in \Omega$ such that $u_{\mathrm{UK}}^{\prime}$ $>u_{\mathrm{UK}}, u_{\mathrm{EU}}^{\prime}>u_{\mathrm{EU}}$ and for some $i, u_{i}^{\prime}>u_{i}$.

Trade integration can be an $x$ offer. Immigration integration ( $Y$ in the indifference curve analysis) can be added to the utility function of the bargaining game in the following way: The set of possible agreements $X=\left\{\left(x_{\mathrm{UK}}, y_{\mathrm{UK}}\right): 0 \leq x_{\mathrm{UK}} \leq 1\right.$ and 0 $\left.\leq y_{\mathrm{UK}} \leq 1\right\}$, where $x_{\mathrm{UK}}$ and $y_{\mathrm{UK}}$ represent the levels of trade and immigration integration obtained by the UK and $1-x_{\mathrm{UK}}$ and $1-y_{\mathrm{UK}}$ those obtained by the EU. Should agreement $x \in X$ at time $t \Delta$ be reached, then the EU payoff is

$$
U_{\mathrm{EU}}\left(x_{\mathrm{EU}}, y_{\mathrm{EU}}\right) \exp (-r t \Delta),
$$

where $x_{\mathrm{EU}}=1-x_{\mathrm{UK}}$ and $y_{\mathrm{EU}}=1-y_{\mathrm{UK}}$ and $r>0$ is the common discount rate of the player at $t \Delta$.

The UK payoffs are

$$
U_{\mathrm{UK}}\left(x_{\mathrm{UK}}, y_{\mathrm{UK}}\right) \exp (-r t \Delta) .
$$

The Pareto frontier $\Omega^{\mathrm{e}}$ of the set $\Omega$ is possible with an agreement that maximizes one player's utility and minimizes that of the other player. It is a concave function $\psi$, which is in the interval $I_{\mathrm{EU}} \subseteq R$ and the interval $I_{\mathrm{UK}} \subseteq R$ with $0 \in I_{\mathrm{EU}}$ and $0 \in I_{\mathrm{UK}}$ and $\psi(0)>0$ as impasse points $\left(I_{\mathrm{EU}}, I_{\mathrm{UK}}\right)$. For each $u_{\mathrm{EU}} \geq$ $0, \psi\left(u_{\mathrm{EU}}\right)=\max U_{\mathrm{UK}}(x)$ subject to $x \in X$ and $U_{\mathrm{EU}}(1$ $\left.-x_{\mathrm{UK}}, 1-y_{\mathrm{UK}}\right) \geq u_{\mathrm{EU}}$. In the Subgame Perfect Equilibrium agreement $x^{*} \in X$ is a solution to

$$
\max _{x \in X} U_{\mathrm{EU}}\left(1-x_{\mathrm{UK}}, 1-y_{\mathrm{UK}} U_{\mathrm{UK}}(x)\right.
$$

Under the assumption that utility functions are differentiable, the first-order conditions show that $\left(x^{*}{ }_{\mathrm{UK}}, y^{*} \mathrm{UK}\right)$ is the unique solution to

$$
\begin{aligned}
& U_{\mathrm{EU}}\left(1-x_{\mathrm{UK}}, 1-y_{\mathrm{UK}}\right) \frac{\partial U u \mathrm{k}}{\partial x u k}=U_{\mathrm{UK}}\left(x_{\mathrm{UK}}, y_{\mathrm{UK}}\right) \frac{\partial U e u}{\partial x e u} \\
& U_{\mathrm{EU}}\left(1-x_{\mathrm{UK}}, 1-y_{\mathrm{UK}}\right) \frac{\partial U u k}{\partial y u k}=U_{\mathrm{UK}}\left(x_{\mathrm{UK}}, y_{\mathrm{UK}}\right) \frac{\partial U e u}{\partial y e u}
\end{aligned}
$$

In the Rubinstein bargaining game, this is the marginal rate of substitution between trade integration and immigration integration:

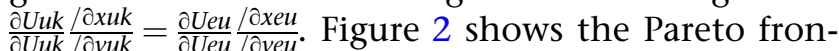
tier for both players, the impasse points and the offer curve of the game. The frontier provides the space within which negotiations will take place and to which behavioral aspects can now be added.

This rational perspective helps identify the options available for Brexit negotiators. In the next section, we deal with the uncertainties and complexities of the negotiation process. They are due to the fact that players adhere to different norms when it comes to information disclosure, use of threats, timing of concessions, standards of fairness, and willingness to enlist the help of mediators and arbitrators (Raiffa et al., 2002; Ott, 2013).

\section{NEGOTIATION ANALYSIS FOR BREXIT}

\section{An Application - Intuition and Real-Life Bargaining Situation}

We now consider utility functions from an intuitive perspective given what we know about the UK and EU. The UK only accounts for about $10 \%$ of total EU trade, and some 3 million EU citizens reside in the UK. The EU utility function $u_{\mathrm{EU}}$ reflects the EU tradeoff between trade and immigration integration given that preserving the open border between

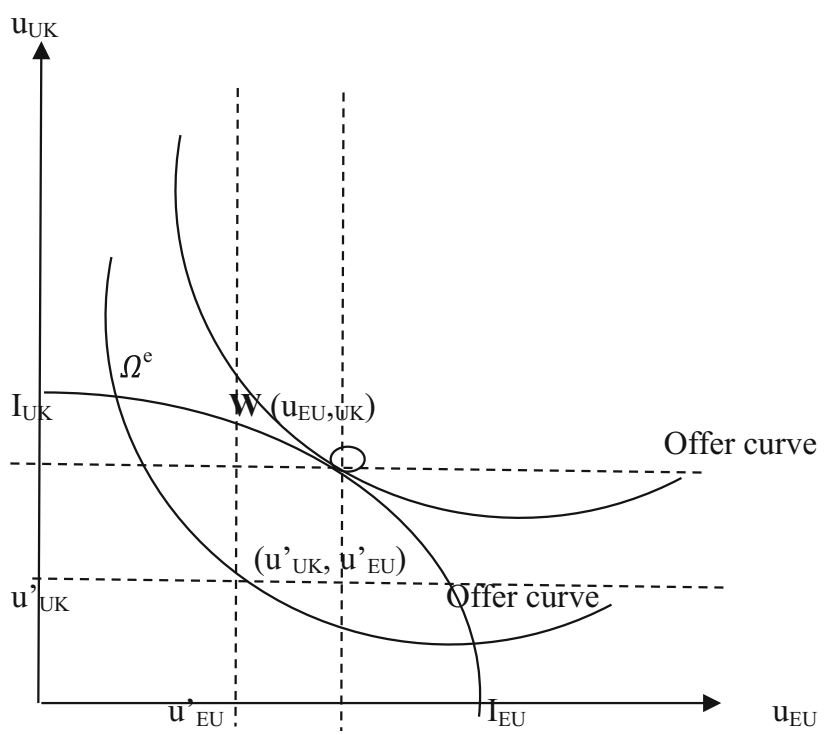

Figure 2 Alternating offer bargaining for the EU and UK. $u_{E U}$ Utility function for the EU $\left(u_{\mathrm{EU}}=U_{\mathrm{EU}}\left(x_{\mathrm{EU}}, y_{\mathrm{EU}}\right)\right), u_{U K}$ utility function for the UK $\left(u_{\mathrm{UK}}=U_{\mathrm{UK}}\left(x_{\mathrm{UK}}, y_{\mathrm{UK}}\right)\right), I_{U K} \mathrm{UK}$ impasse point $I_{\mathrm{EU}} \mathrm{EU}$ impasse point $\Omega^{\mathrm{e}}$ Pareto frontier. 
the Republic of Ireland and Northern Ireland is an additional objective, as is the settling of financial commitments made by the UK, that is, a UK exit payment of $€ 40$ billion negotiated in stage 2 . The UK has a different utility function in which trade integration is important, perhaps most of all the possibility of negotiating trade agreements with third parties, although curtailing immigration from the EU is a main objective.

Stage 1 - Endowment situation For the UK, $U_{\mathrm{UK}}(x$, $y)=u_{\mathrm{UK}}$ and $U_{\mathrm{UK}}\left(x_{\mathrm{UK}}, y_{\mathrm{UK}}\right)=4 x+1.2 y$, with a trade ratio of 4 (40\% of UK trade being with the EU) and 1.2 million UK citizens having emigrated to the EU. For the $\mathrm{EU}, U_{\mathrm{EU}}(x, y)=u_{\mathrm{EU}}$ and $U_{\mathrm{EU}}\left(x_{\mathrm{EU}}, y_{\mathrm{EU}}\right)$ $=x+3 y$, with a trade ratio of $1(10 \%$ of EU trade is with the UK) and 3 million EU citizens having emigrated to the UK. This picture of the situation on the eve of Brexit is reflected in the endowment point and sets the starting point for the negotiations.

Stage 2 - Exit payment negotiations From a negotiation analytical perspective, the EU starting point is a $€ 100$ billion exit payment from the $U K$, as " $Z$ " in an alternating offer game, the UK counter-offered with $€ 20$ billion. After much back and forth, a $€ 40$ billion ( $£ 39$ billion) settlement was agreed. In addition, the rights of UK citizens in the EU and EU citizens in the UK were made reciprocal. There may be any number of such negotiations involving different stakeholders. In the case of Brexit, the UK government must contend with a coalition partner that is in a position to hold it hostage, the Democratic Unionist Party of Northern Ireland. The EU on the other hand determined that in order to preserve the Good Friday Agreement, Northern Ireland and the Republic of Ireland needed to be treated in the same way. The objectives spelled out in the White Paper will be part of negotiations in the next stage of the process. The Northern IrelandRepublic of Ireland situation is very complicated and volatile, so it is not surprising that negotiations related to it would be. Indeed, how the border issues are settled could determine future UK security, even unity.

Stage 3 - Trade agreements We now look more closely at trade agreement options. We again use bargaining results and add the 12 objectives from the White Paper and negotiation outcomes. Continuing current security cooperation is in the interest of both parties and might have been dealt with in calculating the exit negotiation payment, but we can add it as " $\mathrm{s}$ " to the utility function.
$U_{\mathrm{UK}}(x, y)=u_{\mathrm{UK}}$ and $U_{\mathrm{UK}}(x, y)=\alpha_{\mathrm{UK}} x+\beta_{\mathrm{UK}} y-40$ billion exit payment, and $U_{\mathrm{EU}}(x, y)=u_{\mathrm{EU}}$ and $U_{\mathrm{EU}}(x$, $y)=\alpha_{\mathrm{EU}} x+\beta_{\mathrm{EU}} y+40$ billion, where $\alpha$ and $\beta$ are parameters for the variables $x$ and $y$ (trade integration and immigration integration). An Irish border solution "ib" and security " $\mathrm{s}$ " can be added to the utility function for the UK as expressed above. The parameters can reflect the ratio used in the negotiation for trade and/or immigration integration. To capture the uncertainty of the outcome, we can use the expected utility approach and assign probabilities to the feasibility of the agreement. Setting a variable 0 would mean that the preference relation is taken off the utility function. We use only the insights of the bargaining model, which focus on the trade and immigration integration as a bargaining mechanism leading to the package negotiations of complex negotiations (Raiffa et al., 2002) and a behavioral approach.

$u_{\mathrm{UK}} \geq 0$ and $u_{\mathrm{EU}} \geq 0$ are the rationality assumptions for both players. In the case of no deal, $u_{\mathrm{UK}}=0$, but still with an exit payment added to the utility function, which is below the reservation value. The Norway model would have $U_{\mathrm{UK}}(x$, $y)=\alpha_{U K} x+\beta_{U K} y-40$ billion, and an additional payment " $z$ " for access to the single market $U_{\mathrm{UK}}(x$, $y, z)>0$. The Switzerland model would have a utility function of $U_{\mathrm{UK}}\left(x_{\mathrm{N}}\right)$ with only " $x$ " relevant without immigration, but agreements for sectors, financial services in the case of the UK. Finally, "deep and special agreements" would need to be added to $U_{\mathrm{UK}}(x, y)$ and with " $\mathrm{s}$ " for security and " $\mathrm{ib}$ " for the Irish border. We now are able to assign zones in the Pareto frontier where outcomes are potentially feasible.

Figure 3 sets out the utilities of the players, with the Pareto frontier divided into the region of feasible and potential agreements. We use indifference curves and the bargaining outcome of Figure 2 and positions the payoffs of the players in the Pareto frontier. Our analysis shows clearly that the region for trade agreements lies between the impasse points of both players but also beyond the reservation values.

Application of the bargaining theoretical and negotiation analytical approach to the Brexit negotiations and the agreement zone follows a behavioral assumption of uncertainties. Raiffa et al. (2002), Ghauri (2003a, b), and Ott (2011) argue that cultural differences and strategic behavior are reflected in time preferences, action profiles, height of offers, and norms and values. In the next section, we move a step closer to the potentially feasible 


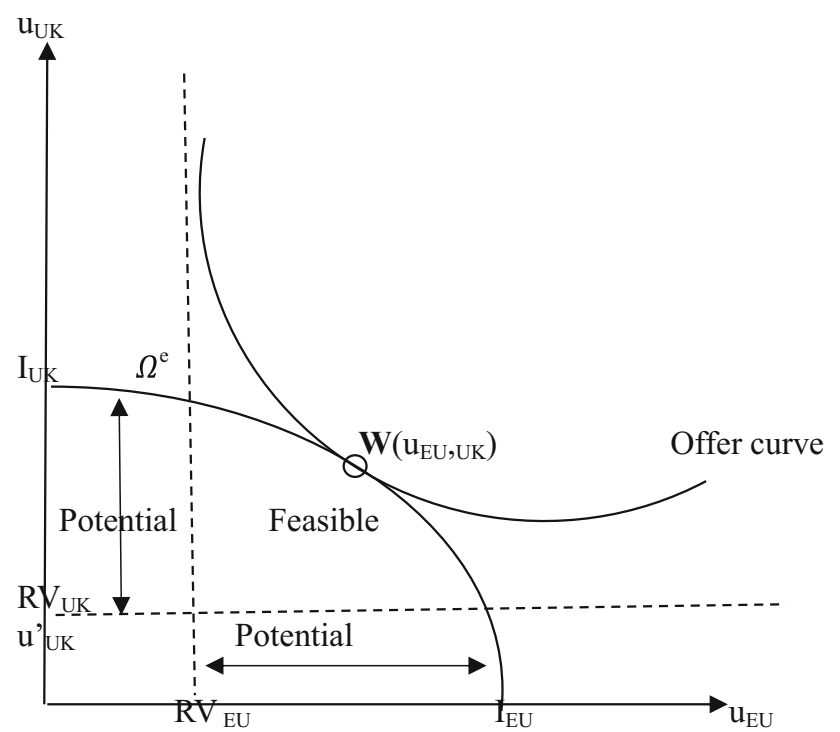

Figure 3 Feasible and potential agreement zones for the EU and UK. $u_{E U}$ Utility function for the EU $\left(u_{\mathrm{EU}}=U_{\mathrm{EU}}\left(x_{\mathrm{EU}}, y_{\mathrm{EU}}\right)\right), u_{U K}$ Utility function for the UK $\left(u_{U K}=U_{U K}\left(x_{U K}, y_{U K}\right)\right), I_{U K} U K$ impasse point UK, $I_{E U}$ EU impasse point EU, $\Omega^{\mathrm{e}}$ Pareto frontier, RV EU and UK reservation values, $W$ EU and UK endowment points.

agreement zones by showing how the best alternative to a negotiated agreement (BATNA) and Brexit strategies can determine negotiation outcomes.

\section{AGREEMENT ZONES FOR BREXIT}

\section{Best Alternative to Negotiated Agreement (BATNA)}

Just like with any other negotiation, in Brexit both sides must calculate the possibility of deadlocks and anticipate possible agreements. If there is an impasse, what are the best outside options? Seasoned negotiators understand the value of determining their BATNA (Fisher, Ury, \& Patton, 1991), otherwise they will not be able to confidently walk away from a subpar offer (Fisher et al., 1991; Subramanian, 2007), thus, UK and EU negotiator experts will be aware of their bargaining power and their BATNA (Fisher et al., 1991; Malhotra, 2004). It is imperative that negotiators calculate the reservation value, that is, the lowest-valued deal acceptable. If the value of the deal proposed is lower than the reservation value, it is better to reject the offer and pursue the BATNA. If the final offer is higher than the reservation value, then acceptance is the best option. In the case of Brexit, it should be determined whether WTO rules, a customs union, the Switzerland model, the Ukraine Plus model, or the Norway model represents the BATNA.

\section{Agreement Strategies and Scenarios}

\begin{abstract}
The EU referendum just gave people the choice to 'Leave the European Union' or 'Remain a member of the European Union', but there are lots of ways we could leave the EU. Hard Brexit is at one end of the spectrum. It is about moving further away from the EU and cutting the main formal ties with the EU ... Soft Brexit is at the other end of the spectrum, where we continue to have close formal ties with the EU." (Full Fact, 2017).
\end{abstract}

Hard Brexit would mean that the UK would not allow free movement of people between the UK and the EU. As the free movement of goods, services, capital, and people is at the core of the EU project, and the EU sees the four as indivisible, a strategy calling for three of the four exposes a problematic UK negotiation style. If the UK follows a hard Brexit strategy, it is likely that there will not be a deal. This would mean that the UK would have to rely on World Trade Organization (WTO) rules. The WTO agreement signed in Marrakesh in 1994, and updated since, serves as an umbrella agreement. It has annexes on intellectual property, dispute settlements, trade-policy review mechanisms, multilateral agreements, and other matters. While the WTO agreement is currently used for EU-US trade, the WTO does not set tariffs or taxes. Its conflict resolution process is exceedingly long, and its remedies are blunt instruments. With only WTO rules as a fallback position, it is clear that negotiation expertise will be important.

Considering the short time horizon, the only successful strategy is to be close to a fair deal from the outset. This would demand that the negotiators put their cards on the table, which the EU negotiators have done in publicizing their strategy and regularly updating information on their approach on their Web sites with supporting information regarding the legal situation after the withdrawal (information acts, customs tariffs, interim solutions for exports, intellectual property rights, etc.).

Soft Brexit, on the other end of the spectrum, would mean having close links to the $\mathrm{EU}$, similar to those of the Norway model. While Norway is not a member of the European Union, it has close trade links with the EU, and is in the EU single market for which it pays about $€ 400$ million annually in grants. The citizens of Norway can move between EU countries freely and citizens of the EU can just as freely move to Norway (Full Fact, 2017). Adopting the Norway model would mean starting with a single market assumption for which the UK would 
have to make financial contributions, which some argue would not be in keeping with the propositions of the White Paper. Moreover, the UK would have to reckon with the fact that the EU often refers to "cooperative exchange" regarding customs tariffs and quotas, which indicates that payments alone would not be acceptable. This said, a soft approach would be a quicker way to reach a settlement.

Mixed strategy profiles or a 'concessionary' Brexit strategy could lead to various ways to access EU goods, services, capital, and labor markets along the lines of the Canada, Turkey, and Ukraine Plus models. The UK negotiation strategy position strongly favors negotiating all these aspects at once. Besides the negotiation strategy profiles, which include strategies related to immigration and trade, other strategies regarding planning, conflict resolution, and deal-making must be included. In this regard, we can draw on the mechanisms identified in the negotiation literature (Raiffa, 1983; Susskind, 2003; Ury, 1991; Malhotra, 2004, 2016). For Brexit, immigration needs to be dealt with first - the rights of UK citizens and EU citizens secured and then perhaps a quota/tier system. Free-trade agreements (FTAs) and bilateral investment treaties (BITs) are the next stage, with an exit payment and tariffs following. This position may entail extreme negotiation behavior, such as haggling, i.e., starting with extreme offers, and quickly reducing bids as concessions to make for a shorter bargaining horizon. On the other hand, it may mean using concessions as a relationshipbuilding approach, which means longer negotiations that bind the parties and make it more difficult for them to opt out, and fair deal behavior for negotiations with a short-term view, i.e., making offers close to what negotiators want in the end (Ott, 2011). Concessions with a longer bargaining horizon give negotiators the opportunity to focus on relationships - thus difficult issues are not negotiated first, but only when a relationship has been established. This is a desirable strategy for the UK depending on background and atmosphere implications (Ghauri, 2003b).

\section{Feasible and Potential Agreements}

Negotiators on opposite sides of the table often have different visions of the future. The zone of possible agreement (ZOPA) can be overshadowed by information asymmetries, moral hazard problems, cultural differences, and complexity costs. However, negotiation theorists offer a way around these (Fischer et al., 1991; Ott, 2011; Subramanian,
2007; Ury, 1991). Before proposing a contingency, negotiators consider potential informational asymmetries and differing incentives that need to be resolved first, including complexity costs that might arise. Without looking forward and reasoning back, a move that could expand the pie might do just the opposite. We are left then with several important questions to address regarding the aims of the UK to find out whether they will be better off after the deal, whether they have considered a BATNA, and how they can create a positive and cordial atmosphere to keep the other side's expectations high during the process. To reduce concerns, Brexit negotiators must consider conflictresolution mechanisms. The EU started with an excellent analytical approach by insisting on stepby-step negotiations. UK negotiators would be wise to do the same, given that the negotiations are complex, uncertain, and to be concluded under intense time pressure.

We now consider the agreement zone between the negotiating parties. The agreement zone reflects possibilities to reach an agreement acceptable to both sides when both parties cooperate (Raiffa, 1983; Ott et al., 2016). We assume that we have three different strategy profiles (hard, soft, and mixed). Depending on the cultural and strategic backgrounds of the negotiators, all three approaches and their response function or counter-offers from the bargaining model can be emphasized.

\section{Reservation Values}

A UK hard Brexit strategy will lead to a narrow agreement zone and tit-for-tat measures (Axelrod, 1984), and the consequence will be that the UK will has to fall back on WTO rules that will result in tariffs and import quotas. The strategy will be on the trade integration axis of Figure 3 on the lower end towards the origin and low on the immigration integration as well (almost zero). The rationale for a hard Brexit is the belief that the UK will benefit after leaving the EU from third-country agreements that will compensate for lower EU trade volume. However many of those third countries, notably China and India arguably the biggest among them, already have trade agreements with the EU, and will want to continue to deal with the world's biggest consumer market that also has the most buying power. 


\section{Potential Agreement}

The White Paper suggests that the UK wants to obtain strong access to the single market, as well as the possibility of signing free-trade agreements with third countries. This would mean European Economic Area (EEA) membership, as Norway has had since 1992. A soft Brexit strategy would mean payment for single market access, but hand-inglove with that would be free movement of people, again like the Norway model. This implies high levels of trade and immigration integration and would define the potential agreement zone for the EU utility functions (along the $x$ axis). However, the UK wants complete control over immigration. In addition, the UK does not want to be subject to rulings by the European Court of Justice (ECJ). In short, the aims of the UK diverge considerably from those of Norway. Alternatively, the UK could use the Switzerland model, which offers access to the single market in specific sectors, although the EU's negotiation position makes it unlikely that it will consider industry-specific arrangements at this point. In any case, the White Paper explicitly rejects acceptance of the free movement of people, and for all intents and purposes the restrictions that Switzerland was allowed to place on the citizens of EU-2 countries (the newest EU members) will come to an end on June 1, 2019. On another front, Switzerland is currently involved in negotiations with the EU over the ECJ role in resolving trade disputes, which means that it is unlikely that the EU would agree to what the UK wants regarding the ECJ.

\section{Feasible Agreement}

The concessionary approach would consider freetrade agreements (FTAs), with third country trade agreements possible, which are low on trade integration but have the possibility to negotiate immigration quotas, since so far, no immigration integration for this option has been considered. A so-called "deep and special partnership" could be based on the Canada model and Ukraine Plus model, which would mean open market access, no free movement of people, and no ECJ oversight. The wide-ranging possibilities pose a complex conundrum for scholars and civil servants. A recent poll of the German Economists Expert Panel (Gäbler et al., 2017) shows that 31\% of respondents believe that the UK will pursue a Ukraine Plus kind of model, $14 \%$ the Norway model, and 23\% the Switzerland model, with some $14 \%$ saying the UK will seek an alternative like a free-trade agreement and $18 \%$ having no idea of what to expect.
Table 3 Currently held beliefs versus insights from our analysis

Currently held beliefs

The Norway, Canada, and Turkey models and also the No Deal option would meet the UK objectives

The UK negotiation strategy can only be "hard" or "soft"

The key to fulfilling the wishes expressed by the majority of YES referendum voters is a customs union or a free-trade agreement

A trade agreement is not compatible with a reduction in immigration

Negotiating a trade agreement is quick and easy
Specific insights of this analysis

The Ukraine Plus model, which so far has not been considered by UK negotiators, aligns best with the principles outlined in the White Paper. The agreement zones would be more easily reached through alternative offers and BATNAs

There is a refined negotiation strategy which allows for a mixed strategy approach that would fit the Ukraine Plus model or a unique UK model. The UK has suggested the Norway model and Canada model - with modifications. The Switzerland model has been rejected by EU negotiators, as it would mean striking agreements particular to some industries and regions

Our analysis shows that indifference curves can be used to express preferences for trade and immigration integration as a ratio, thus showing the existence of tradeoffs and the possibility of designing a trade agreement that maximizes joint utilities

The utility functions of the bargaining approach and Rubinstein solution to the bargaining problem provide a mechanism which shows the connection between trade and immigration integration Trade, immigration, security, an open Irish border, and an exit payment all enter the utility function of both players. The negotiation analysis positions the outcome inside the Pareto frontier in which no player can be worse off. Feasible and potential agreement zones show that all options make both parties worse off than the pre-Brexit endowment situation 
Based on various agreement models, and the BATNAs of the UK and EU, the result may be close to the second trade agreement option set out by the EU-and already agreed between the EU and Canada and the EU and Ukraine. Those agreements fall within the feasible agreement zone shown in Figure 3 but would still be below the initial endowment point of trade and immigration integration $W$, thus both parties will have lower utilities after Brexit (Table 3).

\section{CONCLUSION}

Considering the short time period allowed for Brexit negotiations, the UK government needs to consider especially carefully its strategy profile and possible negotiation outcomes. Then, negotiators can align them with the agreement zones of the two parties. If BATNAs are anticipated, it will also be necessary to plan meticulously the strategy profiles, agreement models, impasse points, and feasible and possible agreement zones.

The UK and EU have such markedly opposed aims and objectives that there could easily be major conflicts. The indifference curves for trade and immigration integration for both suggest that the negotiation space has not yet been grasped. The suggestion by the EU to start with a separate exit negotiation to then be followed by future relationship negotiations was a wise tactic and a rational approach given the asymmetries between the negotiators.

\section{REFERENCES}

Axelrod, R. (1984). The evolution of cooperation. New York: Basic Books.

Buckley, P. J. 2002. Is the international business research agenda running out of steam? Journal of International Business Studies, 33(2): 365-373

Buckley, P., Doh, J. P., \& Benischke, M. 2017. Towards a renaissance in international business research? Big questions, grand challenges, and the future of IB scholarship. Journal of International Business Studies. https://doi.org/10.1057/s41267-017-0102-z.

Casson, M., \& Wadeson, N. 2000. Bounded rationality, metarationality and the theory of international business. In M. Casson (Ed.), Economics of international business: A new research agenda (pp. 94-116). Cheltenham: Edward Elgar Publishing.

Edgeworth, F. Y. 1925. Papers relating to political economy (Vol. II). London: Macmillan.

European Commission, 2017a. Trade negotiations in a Nutshell. http://ec.europa.eu/trade/policy/countries-and-regions/ agreements/. March 12th.

European Commission, 2017b. Fact sheet transparency of negotiations, tradoc 151381 pdf.

European Union, 2017. Key figures on Europe, 2016 Edition of Statistical books, Belgium, pdf.

Fisher, R., Ury, W., \& Patton, B. 1991. Getting to yes: Negotiating agreement without giving in. London: Penguin.
The indifference curve analysis shows the critical positions of the players regarding trade and immigration integration. We compared the features of the agreements between the EU and Norway, Switzerland, Canada, Turkey, and Ukraine, as well as the No Deal option leading to reliance on WTO rules, with the objectives of the UK government. We analyzed alternating bargaining games given the utility functions of the parties based on preferences for trade and immigration integration. The results of the game theoretical bargaining model pave the way for the negotiation analytical part. The insights of the analysis provide the feasible and potential agreement zones for further Brexit negotiations. The Ukraine Plus model can be seen as a feasible option aligned with the objectives of the UK government. A concessionary mixed strategy approach shows a possible outcome and is better than the Norway, Switzerland, or Turkey models, which are potential agreement zones for the UK and EU. The No Deal option falls below the reservation value zone. Regardless of there being a feasible agreement zone, we have shown that the Pareto optimal outcome for both the UK and the $\mathrm{EU}$ is the starting point of the negotiations - the endowment point. Our international negotiation analysis offers a basis on which we, as international business scholars, can export knowledge to other disciplines by using an interdisciplinary approach to analyze an important current phenomenon.

Full Fact, 2017. https://fullfact.org/europe/what-is-hard-brexit/. Accessed 21 Feb 2018.

Gäbler, S., Krause, M., Kremheller, A., Lorenz, L., \& Potrafke, M. 2017. Die Brexit-Verhandlungen - Inhalt und Konsequenzen für das Vereinigte Königreich und die EU. ifo Schnelldienst 70(7): 55-59.

Ghauri, P. N. 2003a. A framework for international business negotiations. In P. N. Ghauri \& J.-C. Usunier (Eds.), International business negotiations (2nd ed., pp. 3-22). Oxford: Pergamon.

Ghauri, P. N. 2003b. The role of atmosphere in negotiations. In P. N. Ghauri \& J.-C. Usunier (Eds.), International business negotiations (2nd ed., pp. 205-219). Oxford: Pergamon.

HM Government, 2017. The United Kingdom's exit from and new partnership with the European Union. Ref: ISBN 9781474140669, Cm 9417 PDF, 1.48 MB, p. 77. www.gov. uk/government/uploads/system/uploads/attachment_data/ file/589191/The_United_Kingdoms_exit_from_and_ partnership_with_the_EU_Web.pdf.

Imai, L., \& Gelfand, M. J. 2010. The culturally intelligent negotiator: The impact of cultural intelligence (CQ) on negotiation sequences and outcomes. Organizational Behavior and Human Decision Processes, 112: 83-98. 
Kalai, E., \& Smorodinski, M. 1975. Other solutions to the Nash bargaining problem. Econometrica, 43: 513-518.

Kapoor, A. 1970. Negotiation strategies in international business government relations: A study in India. Journal of International Business Studies, 1: 21-42.

Lewicki, R. J., Weiss, S. E., \& Lewin, D. 1992. Models of conflict, negotiation and third-party intervention: A review and synthesis. Journal of Organizational Behavior, 13(3): 209-252.

Malhotra, D. 2004. Accept or reject? Sometimes the hardest part of negotiation is knowing when to walk away. Negotiation Newsletter, August, 1-8.

Malhotra, D. 2016. A definitive guide to the Brexit negotiations. Harvard Business Review (Website), August 5.

Mas-Colell, A., Winston, J., \& Green, J. 1995. Microeconomic theory. Oxford: Oxford University Press.

Money, R. B. 1998. International multilateral negotiations and social networks. Journal of International Business Studies, 29(4): 695-710.

Mulabdic, A, Osnago, A., \& Ruta, M. 2017. Deep integration and EU-UK trade relations. World Bank Policy Research Working Paper 7947, pp. 1-24.

Muthoo, A. 1999. Bargaining theory with applications. Cambridge: Cambridge University Press.

Nash, J. 1950. The bargaining problem. Econometrica, 18: 155-162.

Ott, U. F. 2011. The influence of cultural activity types on buyerseller negotiations - A game theoretic framework for international negotiations. International Negotiation Journal, Special Issue on Culture and Negotiations, 16(3): 427-450.

Ott, U. F. 2013. International business research and game theory: Looking beyond the prisoner's dilemma. International Business Review, 22(2): 480-491.

Ott, U. F., Prowse, P., Fells, R., \& Rogers, H. 2016. The DNA of negotiations: A set theoretic analysis. Journal of Business Research, 69(9): 3561-3571.
Pötsch, U., \& Van Roosebeke, B. 2017. "Ukraine Plus" as a model for Brexit: Comments on Theresa May's Brexit plan, Centre for European Policy, cepAdhoc Document, 1-8.

Raiffa, $\mathrm{H}$. 1983. The art and science of negotiation. Cambridge, MA: The Belknap Press of Harvard University Press.

Raiffa, H., Richardson, J., \& Metcalfe, D. 2002. Negotiation analysis: The science and art of collaborative decision making. Cambridge, MA: The Belknap Press of Harvard University Press.

Rubinstein, A. 1982. Perfect equilibrium in a bargaining model. Econometrica, 50: 97-110.

Sawyer, J., \& Guetzkow H. 1965. Bargaining and Negotiation in international Relations. In H. C. Kelman (Ed.), International behavior. New York: Holt, Rhinehart, and Winston.

Subramanian, G. 2007. Taking BATNA to the next level. Negotiation Briefings, November, 17-20.

Susskind, L. 2003. When an angry public wants to be heard. Negotiation newsletter, November, 5-6.

Tung, R. L. 1982. US-China trade negotiations: Practices, procedures and outcomes. Journal of International Business Studies, 13: 25-37.

Ury, W. 1991. Getting past no: Negotiating with difficult people. Bantam: Bantam Books.

Volkema, R. J. 2012. Why people don't ask: Understanding initiation behavior in international negotiations. Thunderbird International Business Review, 54(5): 625-637.

Walton, R. E., \& McKersie, R. B. 1965. A behavioral theory of labor negotiations: An analysis of a social interaction system. New York: McGraw-Hill.

\section{APPENDIX: GLOSSARY OF TECHNICAL TERMS}

\begin{tabular}{ll}
\hline Technical term & Explanation \\
\hline Edgeworth box (Edgeworth, 1925) & $\begin{array}{l}\text { A common tool in general equilibrium analysis which allows the study of the interaction of } \\
\text { two individual parties trading two different commodities. Exchange ratios between } \\
\text { commodities are determined through an hypothesized auction process } \\
\text { The curve of each party which shows equal utility for the two commodities traded. Along the } \\
\text { indifference curve, any combination of the two commodities yields equal satisfaction. In the } \\
\text { case of exit negotiations, each point on an indifference curve gives equal satisfaction for any } \\
\text { combination of trade and immigration } \\
\text { exit negotiations) }\end{array}$ \\
$\begin{array}{l}\text { The utility function } \mathrm{u}(x) \text { assigns a numerical value to each element in } X, \text { ranking them in } \\
\text { accordance with an individual's preferences } \\
\text { Utility function }\end{array}$ & $\begin{array}{l}\text { The space in the Edgeworth box, where both parties have the possibility to negotiate a deal } \\
\text { due to the joint set of exchange possibilities marked by the shape of the indifference curves } \\
\text { between } R \text { and W }\end{array}$ \\
Negotiation space & $\begin{array}{l}\text { Assets at the beginning of the transactions, which can be financial or non-pecuniary } \\
\text { The space between the two parties, which has been derived from both sides offering over a } \\
\text { period of time. The zone shows the space where contracts and deals are arrived at }\end{array}$ \\
Initial endowment &
\end{tabular}

\section{ABOUT THE AUTHORS}

Ursula F Ott completed her Ph.D. at the University of Vienna in Austria where she also taught for some years as a Lecturer. Over the years, she has been working as Research Scholar at the London
School of Economics, as Senior Lecturer at Loughborough University and as Professor of International Business at Kingston University in the UK. Currently, Ursula is Professor of International Business at Nottingham Trent University in the UK. 
Ursula has published books and articles in leading journals such as Journal of International Business Studies, Organization Studies, Journal of Management Studies, International Business Review and Journal of Business Research.

Pervez N Ghauri completed his Ph.D. at Uppsala University (Sweden) where he also taught for several years. Currently, Pervez is Professor of International Business at University of Birmingham (UK). Recently, he was awarded an Honorary Doctor of Economics by University of Vaasa (Finland). Pervez is the Editor-in-Chief of the International Business Review. Pervez is a Fellow for both the European International Business Academy (EIBA) and the Academy of International Business (AIB), where he was also Vice President between 2008 and 2010. Pervez has published around 30 books and numerous articles in top-level journals.

Open Access This article is distributed under the terms of the Creative Commons Attribution 4.0 International License (http://creativecommons. org/licenses/by/4.0/), which permits unrestricted use, distribution, and reproduction in any medium, provided you give appropriate credit to the original author(s) and the source, provide a link to the Creative Commons license, and indicate if changes were made. 